\title{
First record of two sublittoral amphipods from Hawai'i
}

\author{
Ken Longenecker(iD
}

\begin{abstract}
The first record of two genera of sublittoral amphipods, Autonoe Bruzelius, 1859 and Perioculodes G.O. Sars, 1892, is provided for Hawai'i. The specimens most closely match Autonoe seurati (Chevreux 1907) and Perioculodes aequimanus (Kossmann, 1880). They were collected from an autonomous reef monitoring structure deployed in Honolulu Harbor, O'ahu. Both species are likely recent introductions.
\end{abstract}

Keywords: Aoridae, Autonoe, Oedicerotidae, Perioculodes, Honolulu Harbor, O'ahu

\section{Introduction}

The first major review of the sublittoral amphipods of the Hawaiian Islands (Barnard 1971; Barnard 1970) expanded the known species from $\sim 40$ to $\sim 120$. In 1992 the Hawaii Biological Survey (HBS) initiated an ongoing natural history inventory of the Hawaiian Archipelago to locate, identify, and evaluate all species within the state (Evenhuis and Miller 2015). As of 1995, the HBS checklist contained 181 amphipods (Eldredge and Miller 1995). That list was last expanded to 201 with the discovery of a new species in 2006 (Longenecker and Bolick 2007).

In 2019, the aquatic invasive species team from the State of Hawai'i's Division of Aquatic Resources began using autonomous reef monitoring structures (ARMS) to monitor state harbors. ARMS are standardized structures designed to passively sample understudied marine cryptofauna (Global ARMS Program 2017). The first ARMS unit to be processed included specimens of two amphipod genera not previously reported from Hawai'i.

\section{Methods}

A modified ARMS, consisting of four plates rather than the standard nine, was deployed 10 July 2018 in Honolulu Harbor on the island of O'ahu, Hawai'i, USA. The unit was placed at $3.66 \mathrm{~m}$ depth on hard substrate at

Correspondence: klongenecker@bishopmuseum.org

Bishop Museum, 1525 Bernice Street, Honolulu, Hawaii 96817, USA $21.30466^{\circ} \mathrm{N}, 157.870861^{\circ} \mathrm{W}$, and retrieved 12 August 2019. All crustaceans retained on a $2-\mathrm{mm}$ sieve were received by the author on 23 April 2020.

The two amphipod species reported herein were dissected and observed following the procedure outlined in Barnard (1971). Generic determination was accomplished with a guide to the families and genera of marine amphipods (Barnard and Karaman 1991a; Barnard and Karaman 1991b). Tentative species determination was accomplished by reference to the publications cited in the species accounts, below. All specimens were deposited at Bishop Museum.

\section{Results}

SYSTEMATICS

Phylum ARTHROPODA von Siebold, 1848

Class MALACOSTRACA Latreille, 1802

Order AMPHIPODA Latreille, 1816

Suborder SENTICAUDATA Lowry \& Myers, 2013

Family AORIDAE Stebbing, 1899

Genus Autonoe Bruzelius, 1859

Material examined: Collection sites described in methods (4 unsexed individuals, 1 female, BPBM S18524).

Specimen morphology most closely matched the descriptions and illustrations of Autonoe seurati (Chevreux 1907) by Chevreux (1907a), Ledoyer (1984), and Myers (2009). Photographs of the gnathopods and a whole female are presented in Fig. 1. 

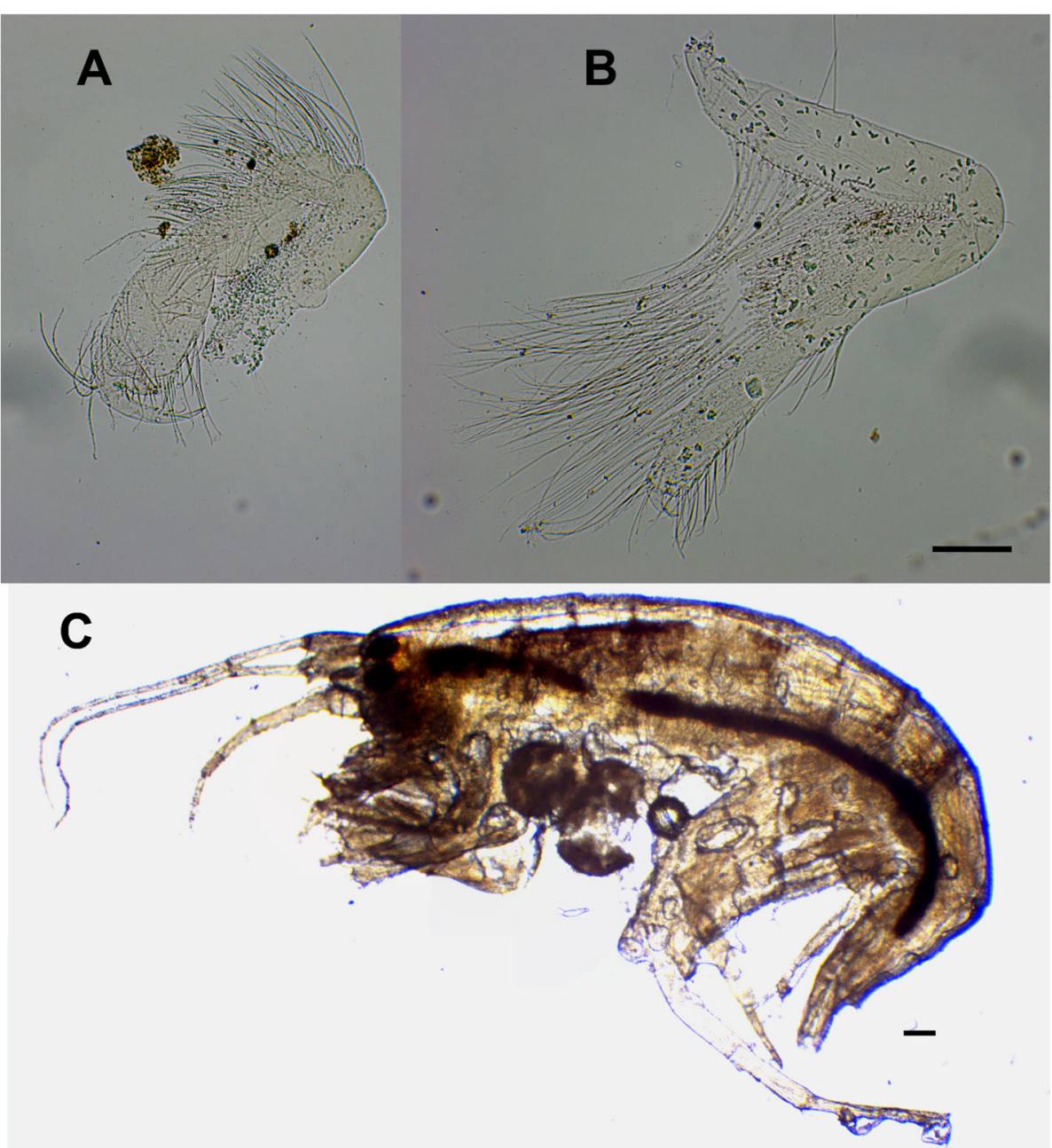

Fig. 1 Autonoe seurati gnathopods 1 (a), 2 (b), and whole female (c). Scale bar $=0.1 \mathrm{~mm}$

Suborder AMPHILOCHIDEA Boeck, 1871

Family OEDICEROTIDAE Lilljeborg, 1865

Genus Perioculodes G.O. Sars, 1892

Material examined: Collection sites described in methods (37 unsexed individuals, BPBM S18514).

Specimen morphology most closely matched the descriptions and illustrations of Perioculodes aequimanus (Kossmann 1880) by Esquete et al. (2010), Myers (1990), and Schellenberg (1928). Photographs of the gnathopods and a whole individual are presented in Fig. 2.

\section{Discussion}

Tentative species-level determinations were made herein. However, despite the Hawaiian marine amphipod fauna being well described and the sample location being well studied, it is possible that one or both are undescribed species. For instance, Perioculodes aequimanus tentatively reported from Australia (Barnard 1931; Lowry and Stoddart 2003) was subsequently described as a new species, $P$. talboti (Hughes and Lowry 2009). Final determination of the Hawaiian specimens will require further analyses (e.g., comparison with type specimens from the type locality, molecular characterization).

Because they exhibit six of the 10 predicted attributes of introduced peracarid species (Chapman and Carlton 1991), both genera are likely to be recent introductions to Hawai $i$. Each attribute is discussed below.

Both genera were previously unknown in the local region. Neither genus was detected in 1997 or 2008 surveys designed to detect nonindigenous marine species introductions in Honolulu Harbor (Coles et al. 2009; Coles et al. 1999).

There is a likely human mechanism of introduction. For centuries, ship fouling has been the primary human mechanism of dispersing marine organisms (Chapman and Carlton 1991); Honolulu Harbor is the Hawai'i's principal seaport.

Both genera were collected with known introductions. Also collected by the ARMS unit were the cryptogenic 


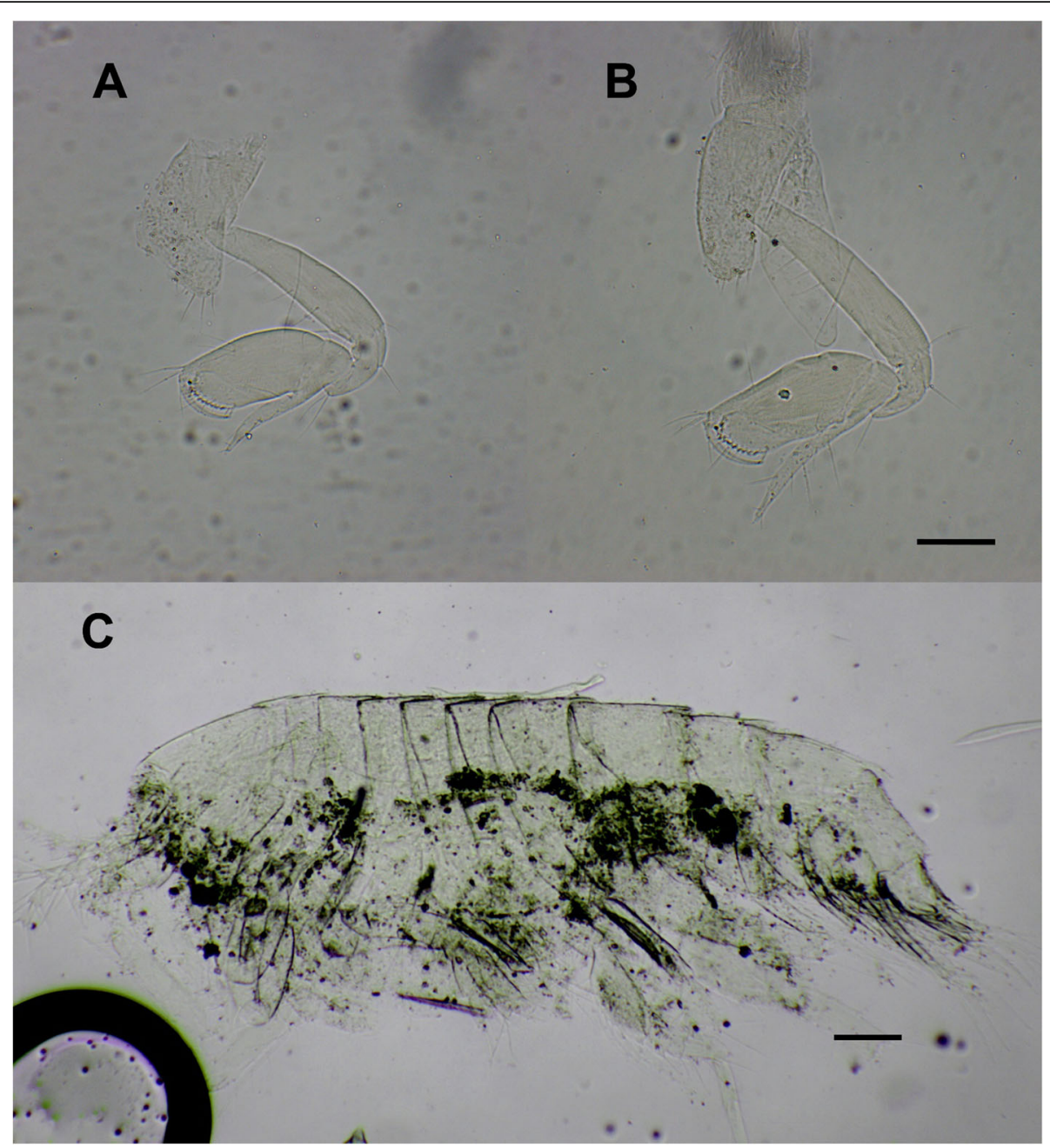

Fig. 2 Perioculodes aequimanus gnathopod 1 (a), 2 (b), and whole individual (c). Scale bar $=0.1 \mathrm{~mm}$

tanaid Chondrochelia dubia (Krøyer 1842) and unidentified cumaceans. The latter were unknown in Hawai $i$ prior to 1996, suggesting that all cumaceans are introduced (Carlton and Eldredge 2009).

Both genera are associated with new or artificial environments. Dredge and fill activities have resulted in extensive modifications to and very little natural substrate remaining in Honolulu Harbor (Coles et al. 2009). Additionally, the ARMS unit from which the genera were collected are anthropogenic structures.

Assuming the species determinations herein are correct, both species have a disjunct global distribution. Autonoe seurati was described from the Pacific Ocean at French Polynesia (Chevreux 1907b). It was subsequently reported from Fiji (Schellenberg 1938) and New Caledonia (Ledoyer 1984). It was tentatively identified (Moore 1988), and later confirmed (Myers 2009) from Australia. Perioculodes aequimanus was described from the Red Sea (Kossmann 1880). It was later reported from the
Suez Canal (Schellenberg 1928), then from the Mediterranean coast of France (Ledoyer 1972). It was subsequently reported throughout Mediterranean waters (Esquete et al. 2010). It was tentatively identified from Brazil (Serejo 1998), and confirmed to occur in Atlantic waters when reported from Spain (Esquete et al. 2010). Perioculodes aequimanus was first reported from the Pacific when found in the Cook Islands (Myers 1990).

Neither genus has a sufficient life history adaptation for global dispersal. It is well known that all peracarid crustaceans brood their young to a juvenile stage (Strathmann and Strathmann 1982). Thus, neither genus has the ability to undergo long-range larval dispersal.

Two additional attributes, post-introduction range expansion and discontinuous regional distribution, could not be assessed by the identification of amphipods collected from a single ARMS unit. Monitoring Hawai'i's other harbors, as well as non-harbor habitats, would allow the evaluation of those attributes. 


\section{Conclusions}

Two genera of sublittoral amphipods, Autonoe and Perioculodes, are reported from Hawai'i (and the North Pacific) for the first time. Both are likely to have been introduced since 2008. Additional monitoring of Hawai'i's harbors and nearby habitats would help to clarify whether the amphipods are introduced and, if so, detect whether they are expanding their range.

\section{Abbreviations}

ARMS: Autonomous Reef Monitoring Structure; HBS: Hawaii Biological Survey

\section{Acknowledgements}

Holly Bolick obtained and managed both sources of funding that permitted this publication. This is contribution 2021-001 to the Hawaii Biological Survey.

\section{Author's contributions}

$\mathrm{KL}$ performed taxonomic work and prepared the manuscript. The author(s) read and approved the final manuscript.

\section{Funding}

Taxonomic work was funded by the State of Hawaii, Department of Land and Natural Resources, Division of Aquatic Resources through the "Taxonomic identification and potential genetic analysis support for the DAR Aquatic Invasive Species (AIS) team's Autonomous Reef Monitoring Structure (ARMS) Harbor Monitoring Project", manuscript preparation was funded by the Charles H. \& Margaret B. Edmondson Charitable Trust.

\section{Availability of data and materials}

All specimens are deposited at Bishop Museum.

\section{Declarations}

Ethics approval and consent to participate

Not applicable.

\section{Consent for publication}

Not applicable.

\section{Competing interests}

The author declares that he has no competing interests.

Received: 30 December 2020 Accepted: 24 March 2021

Published online: 14 April 2021

\section{References}

Barnard JL. Sublittoral Gammaridea (Amphipoda ) of the Hawaiian islands. Smithson Contrib Zool. 1970;34:1-296.

Barnard JL. Keys to the Hawaiian marine Gammaridea, 0-30 meters. Smithson Contrib Zool. 1971:58:1-135.

Barnard JL, Karaman GS. The families and genera of marine gammaridean Amphipoda (except marine gammaroids). Part 1. Rec Aust Museum Suppl. 1991a;13(1):1-417. https://doi.org/10.3853/j.0812-7387.13.1991.91.

Barnard $J \mathrm{~L}$, Karaman GS. The families and genera of marine gammaridean Amphipoda (except marine gammaroids). Part 2. Rec Aust Museum Suppl. 1991b:13(2):419-866. https://doi.org/10.3853/j.0812-7387.13.1991.367.

Barnard KH. Amphipoda. Great barrier reef expedition 1928-29. Sci Rep. 1931;4(4): 111-35.

Carlton JT, Eldredge LG. Marine bioinvasions of Hawai'i. the introduced and cryptogenic marine and estuarine animals and plants of the Hawaiian archipelago. Honolulu: Bishop Museum Press; 2009. Bish. Museum Bull. Cult. Environ. Stud

Chapman JW, Carlton JT. A test of criteria for introduced species: the global invasion by the isopod Synidotea laevidorsalis (Miers, 1881). J Crustac Biol. 1991:11(3):386-400. https://doi.org/10.2307/1548465.

Chevreux E. Amphipodes recueillis dans les possessions françaises de l'Océanie par M. le Dr. Seurat, directeur du laboratoire de recherches biologiques de Rikitea (îles Gambier) 1902-1904. Mém Soc Zool Fr. 1907a;20:470-527.
Chevreux E. Diagnoses d'amphipodes nouveaux recueillis dans les possessions francaises de l'Oceanie, par M.L. Seurat Directeur du laboratoire de recherches biologiques de Rikitea. Bull Museum Natl d'Histoire Nat. 1907b; 13(6):412-7.

Coles SL, Bolick H, Hauk B, Montgomery A. Ten year resurveys of the biodiversity of marine communities and introduced species in Pearl Harbor, Honolulu Harbor, and Ke'ehi lagoon, O'ahu, Hawai'i. Bish Museum Tech Rep. 2009;4:1204

Coles SL, DeFelice R, Eldredge LG. Nonindigenous marine species introductions in the harbors of the south and west shores of Oahu, Hawaii. Bish Museum Tech Rep. 1999;15:1-212.

Eldredge LG, Miller SE. How many species are there in Hawaii. Bish Museum Occas Pap. 1995:41:3-18.

Esquete P, Moreira J, Troncoso JS. First record of Perioculodes aequimanus (Crustacea: Amphipoda) in the north-East Atlantic, with remarks on taxonomic characters. Mar Biodivers Rec. 2010;3:1-7.

Evenhuis NL, Miller SE. Records of the Hawaii Biological Survey for 2014 part II: index. Bish Museum Occassional Pap. 2015;117:1-2

Global ARMS Program. Front Page | Autonomous Reef Monitoring Structures [Internet]. 2017. https://www.oceanarms.org/. [Accessed 9 Dec 2020].

Hughes LE, Lowry JK. Oedicerotidae. In: Lowry JK, Myers AA, editors. Benthic Amphipoda (Crustacea: Peracarida) of the great barrier reef, Australia, vol. 2260. Auckland: Magnolia Press; 2009. p. 746-58.

Kossmann R. Malacostraca. In: Kossmann R, editor. Zool, ergebnisse einer im auftrage der Königlichen Acad. der Wissenschaften zu Berlin ausgeführten Reise die Küstengebiete des Rothen Meeres. Leipzig: Verlag von Wilhelm Engelmann; 1880. p. 67-140.

Ledoyer M. Presence de Perioculodes aequimanus (Kossmann) dans le eaux mediterraneennes (region de Marseille) et comparaison avec P. longimanus (Bate et Westwood) (Crustacea, Amphipoda). Bull Museum Natl d'Histoire Nat Paris Ser 3 Zool. 1972:49:775-81.

Ledoyer M. Les gammariens (Crustacea, Amphipoda) des herbiers de phanérogames marines de Nouvelle Calédonie (région de Nouméa). Mém Muséum Natl d'Histoire Nat Nouv Sér/ Sér A/ Zool. 1984;129:1-113.

Longenecker K, Bolick H. A new species of Pseudambasia (Crustacea: Amphipoda: Lysianassidae) from Hawai'i, with a key to species in the genus. Bish Museum Occas Pap. 2007:95:3-8

Lowry JK, Stoddart HE. Crustacea: Malacostraca: Peracarida: Amphipoda, Cumacea, Mysidacea. In: Beesley PL, Houston WWK, editors. Zoological Catalogue of Australia, Vol. 19.2B, 531. Melbourne: CSIRO; 2003. p. 203.

Moore PG. Taxonomic observations on the genera Xenocheira Haswell and Ericthonius Milne Edwards (Crustacea: Amphipoda) from Australian coastal waters. J Nat Hist. 1988;22(3):705-32. https://doi.org/10.1080/0022293 8800770461

Myers AA. Amphipoda from the South Pacific: the Cook Islands. Rec Aust Museum. 1990:42(2):149-57. https://doi.org/10.3853/j.0067-1975.42.1990.112.

Myers AA. Aoridae. In: Lowry JK, Myers AA, editors. Benthic Amphipoda (Crustacea: Peracarida) of the Great Barrier Reef, Australia, vol. 2260. Auckland: Magnolia Press; 2009. p. 220-78

Schellenberg A. Report on the Amphipoda. Trans Zool Soc London. 1928:22:63392.

Schellenberg A. Litorale Amphipoden des tropischen Pazifiks nach Sammlungen von Prof. Bock (Stockholm), Prof. Dahl (Berlin) und Prof. Pietschmann (Wein). Kungliga Sven Vetenskapsakademiens Handl Ser 3. 1938;16(6):1-105.

Serejo CS. Gammaridean and caprellidean fauna (Crustacea) associated with the sponge Dysidea fragilis Johnston at Arraial do Cabo, Rio de Janeiro, Brazil. Bull Mar Sci. 1998:63(2):363-85.

Strathmann RR, Strathmann MF. The relationship between adult size and brooding in marine invertebrates. Am Nat. 1982:119(1):91-101. https://doi. org/10.1086/283892.

\section{Publisher's Note}

Springer Nature remains neutral with regard to jurisdictional claims in published maps and institutional affiliations. 